\title{
Oligodendrocytes and CNS Myelin Are Nonpermissive Substrates for Neurite Growth and Fibroblast Spreading in vitro
}

\author{
Martin E. Schwab and Pico Caroni \\ Brain Research Institute of the University of Zurich, $\mathrm{CH}-8029$ Zurich, Switzerland
}

To study the interaction of neurons with CNS glial cells, dissociated sympathetic or sensory ganglion cells or fetal retinal cells were plated onto cultures of dissociated optic nerve glial cells of young rats. Whereas astrocytes favored neuron adhesion and neurite outgrowth, oligodendrocytes differed markedly in their properties as neuronal substrates. Immature $\left(\mathrm{O}_{4}^{+}, \mathrm{A}_{2} \mathrm{~B}_{5}^{+}, \mathrm{GalC}^{-}\right)$oligodendrocytes were frequently contacted by neurons and neurites. In contrast, differentiated oligodendrocytes $\left(\mathrm{O}_{4}{ }^{\prime}, \mathrm{A}_{2} \mathrm{~B}_{5}{ }^{-}, \mathrm{GalC}^{+}\right)$represented a nonpermissive substrate for neuronal adhesion and neurite growth. When neuroblastoma cells or 3T3 fibroblasts were plated into optic nerve glial cultures, the same differences were observed; differentiated oligodendrocytes were nonpermissive for cell adhesion, neurite growth, or fibroblast spreading. These nonpermissive oligodendrocytes were characterized by a radial, highly branched process network, often contained myelin basic protein, and may, therefore, correspond to cells actively involved in the production of myelin-like membranes.

Isolated myelin from adult rat spinal cord was adsorbed to polylysine-coated culture dishes and tested as a substrate for peripheral neurons, neuroblastoma cells, or 3T3 cells. Again, cell attachment, neurite outgrowth, and fibroblast spreading was strongly impaired. General physicochemical properties of myelin were not responsible for this effect, since myelin from rat sciatic nerves favored neuron adhesion and neurite growth as well as spreading of 3T3 cells. These results show that differentiated oligodendrocytes express nonpermissive substrate properties, which may be of importance in CNS development or regeneration.

The reasons why the regeneration of lesioned fiber tracts is almost totally absent in the CNS of higher vertebrates have remained unknown up to now. Transplantation studies of pieces of peripheral nerves into the adult CNS clearly demonstrated the capacity of most types of CNS neurons for regenerative growth and elongation of their processes over long distances

\footnotetext{
Received July 7, 1987; revised Sept. 29, 1987; accepted Nov. 6, 1987.

We thank Ch. Müller (Munich), J. Erni, and L. Steinberg for their skillful technical assistance. Initial experiments were done at the Max-Planck-Institute for Psychiatry, Department of Neurochemistry, Martinsried/Munich. We thank Dr. H. Thoenen for his generous support and interest. The gift of antibodies by Drs. D. Dahl (Boston), F. Omlin (Lausanne), M. Schachner (Heidelberg), and M. Willard (St. Louis) is gratefully acknowledged. We are grateful to Mrs. S. Kaufmann for typing and to Dr. D. Kuffler for critically reading the manuscript.

This work was supported by the Swiss National Foundation for Scientific Research (Grant 3.043-0.84) and the Bonizzi-Theler Foundation (Zurich).

Correspondence should be addressed to Prof. M. E. Schwab, Brain Research Institute of the University of Zurich, August-Forel-Strasse 1, 8029 Zurich, Switzerland.
}

Copyright (C) 1988 Society for Neuroscience $0270-6474 / 88 / 072381-13 \$ 02.00 / 0$
(Tello, 1911; Ramon y Cajal, 1928; Benfey and Aguayo, 1982; Richardson et al., 1984; So and Aguayo, 1985). These studies assigned a crucial role to the microenvironment of the growing fibers, whereby peripheral nerve tissue should allow, support, or provoke neurite regeneration. The involvement of neurotrophic and neurotropic factors - produced by Schwann cells but not by CNS glia - was suggested 60 years ago by Ramon y Cajal (1928). In fact, a marked increase in the production of neurotrophic factors and cell adhesion molecules by Schwann cells in response to denervation has recently been observed (Richardson and Ebendal, 1982; Longo et al., 1984; Abrahamson et al., 1986; Daniloff et al., 1986). However, neurotrophic factors are also present in developing and adult CNS, and increased neurotrophic activities were found at sites of CNS lesions (Barde et al., 1982; Korsching et al., 1985; Whittemore et al., 1985, 1986, 1987; Needels et al., 1986; Shelton and Reichardt, 1986).

Recent in vitro studies, in which dissociated sensory or sympathetic neurons were confronted with explants of adult rat sciatic (PNS) or optic (CNS) nerves, showed that the differences in regenerative neurite growth within peripheral or central nervous tissue environments persisted in the presence of high amounts of a neurotrophic factor (NGF) (Schwab and Thoenen, 1985). In the same cultures, in which up to several hundred axons could be found in the sciatic nerve explants, neurite ingrowth into optic nerves was strictly abscnt. The same findings were obtained with previously frozen optic and sciatic nerves that were free of living glial cells. These results strongly argue against the hypothesis that the lack of CNS regeneration is mainly due to an absence, or insufficient production, of neurotrophic factors by denervated glial cells (Ramon y Cajal, 1928). Rather, the differentiated CNS may lack cellular or substrate constituents conducive for neurite growth during development (Liesi, 1985a; Carbonetto et al., 1987), or it may contain components that are nonpermissive or inhibitory for nerve fiber regeneration.

In the present study, dissociated sympathetic, sensory, or retinal neurons were added to cultures of dissociated CNS glial cells grown at low cell density. One cell type with the characteristics of a differentiated oligodendrocyte forming myelin membranes was found to be highly nonpermissive for neurite growth. This cell contact-mediated, nonpermissive substrate effect was observed for primary culture neurons, neuroblastoma cells, and spreading 3T3 fibroblasts. Isolated myelin from the CNS, but not myelin from sciatic nerves, likewise inhibited neurite growth and fibroblast spreading.

\section{Materials and Methods}

Glial cell cultures. Optic nerves were disscetcd from 7- to 12-d-old or young adult $(180-220 \mathrm{gm})$ Wistar rats and collected in plating medium 
(air-buffered enriched $\mathrm{L}_{15}$ with $5 \%$ rat serum; Mains and Patterson, 1973). The meninges and blood vessels were carefully removed under a microscope, and the nerves were cut into small pieces. Dissociation of young nerves was done twice for $25 \mathrm{~min}$ each in $0.25 \%$ trypsin (Sigma) and $0.02 \%$ collagenase (Worthington) (Raff et al., 1979) in CMFPBS $\left(\mathrm{Ca}^{2+} / \mathrm{Mg}^{2+}\right.$-free PBS) at $37^{\circ} \mathrm{C}$. Adult optic nerves were dissociated in $0.1 \%$ trypsin, $0.1 \%$ collagenase for $1 \mathrm{hr}$ at $37^{\circ} \mathrm{C}$, followed by $0.5 \%$ trypsin for $10 \mathrm{~min}$. After washing and dissociation by trituration with a Pasteur pipet, the cells were plated into the wells of $35 \mathrm{~mm}$ tissue culture dishes containing 4 internal wells at a density of $20,000-30,000$ cells/well (surface of well, $95 \mathrm{~mm}^{2}$ ). For 7 - to 10-d-old optic nerves, the yield was about 10,000 cells per nerve. The culture substrate for most of the experiments was polyornithine (PORN, Sigma, $0.5 \mathrm{mg} / \mathrm{ml}$ in borate buffer, incubated overnight) or polylysine (PLYS, Sigma, $50 \mu \mathrm{g} /$ $\mathrm{ml}$ in water); in some experiments, a dried collagen film (calf skin collagen, incubation overnight with sterile solution), laminin-coated PORN [purified mouse EHS tumor laminin (gift of Dr. R. Timpl, Munich), $5 \mu \mathrm{g} / \mathrm{ml}$, incubated for $3 \mathrm{hr}$ on dishes previously coated with PORN], or plain tissue culture plastic was used. The culture medium was an enriched $L_{15}$ medium with $5 \%$ rat serum, penicillin $(100 \mathrm{U} / \mathrm{ml})$, and streptomycin $(100 \mu \mathrm{g} / \mathrm{ml})$ (Mains and Patterson, 1973). In some experiments, $10 \%$ fetal calf serum (FCS) was added instead of the rat serum.

Optic nerves of E13 or E17 chicken embryos were dissociated by brief trypsin/collagenase treatment and cultured for $2-7 \mathrm{~d}$ in $\mathrm{L}_{15}$ with $5 \%$ FCS on PORN-coated culture dishes.

Glia-nerve cell cocultures. Three different types of nerve cells were cocultured with glial cells: sympathetic neurons from the superior cervical ganglion of newborn rats, sensory neurons from dorsal root ganglia of newborn rats, or cells from the retina of E17-E18 embryonic rats. Superior cervical and dorsal root ganglia were dissected and dissociated into single cells as described by Mains and Patterson (1973) and Schwab and Thoenen (1985). Retinas were dissected from the embryos, cleaned from adhering blood vessels, incubated in $0.03 \%$ trypsin and $0.03 \%$ DNAase for $10 \mathrm{~min}$ at $37^{\circ} \mathrm{C}$, washed by centrifugation in serum-containing medium, and dissociated by trituration.

The neurons were added to 2- to 10-d-old glial cultures in the same medium, with the addition of NGF (2.5S NGF, 50 or $100 \mathrm{ng} / \mathrm{ml}$ ) for sensory and sympathetic neurons or brain-derived neurotrophic factor for the retinal cells (Johnson et al., 1986). In order to suppress the Schwann cells added together with the peripheral neurons, pulses of cytosine arabinoside (Ara C; $10^{-5} \mathrm{M}$ ) were given twice for $24 \mathrm{hr}$ on the 2 nd and 5 th $d$ of coculture in some experiments. The cultures were processed for antibody staining after $1-5 \mathrm{~d}$ of coculture in the case of retinal cells or after $2 \mathrm{~d}-3$ weeks in the case of peripheral ganglion cells.

Mouse neuroblastoma cells (line NB-2A) cultured in DMEM $/ 10 \%$ FCS were detached from the culture flasks by a brief treatment with $0.1 \%$ trypsin in CMF-Hank's solution terminated by addition of DMEM/ FCS. After washing, the cells were added to glial cultures $(40,000$ or 20,000 cells/well) in DMEM/FCS with either $2 \mathrm{mM}$ dibutyryl-cyclic AMP or glia-derived neurite-promoting factor (GdNPF) (Guenther et al., 1986).

Mouse NIH $3 T 3$ cells, treated identically to the neuroblastoma cells, were added to 2- to 3-d-old cultures of 7-d-old or newborn rat optic nerves at a concentration of 20,000 or 40,000 cells/well in DMEM containing $10 \%$ fetal calf serum or in MEM $\alpha$ supplied with insulin (20 $\mathrm{ng} / \mathrm{ml})$ and transferrin $(50 \mathrm{ng} / \mathrm{ml})$. Cultures were returned to the incubator for $2-4 \mathrm{hr}$ and then fixed with warm $4 \%$ formalin in phosphate buffer and double-stained with the $\mathrm{O}_{1}$ and $\mathrm{O}_{4}$ antibodies.

Immunofluorescence. The following antibodies as markers for oligodendrocytes, astrocytes, neurons, or fibroblasts were used: oligodendrocytes: mouse monoclonal antibody $(\mathrm{m}-\mathrm{AB}) \mathrm{O}_{4}$ (Sommer and Schachner, 1981); mouse m-AB O, (Sommer and Schachner, 1981); specific for galactocerebroside (GalC; Singh and Pfeiffer, 1985); and goat antiserum against myelin basic protein of rabbits (Omlin et al., 1982); precursor cells: mouse m-AB $\mathrm{A}_{2} \mathrm{~B}_{5}$ (Sera-Lab, Crawley Down, GB); astrocytes: rabbit antiserum against glial fibrillary acid protein (GFAP) (Dahl and Bignami, 1976); neurons: mouse $\mathrm{m}-\mathrm{AB}$ against guinea pig or rabbit neurofilaments (Willard and Simon, 1981); fibroblasts: mouse m$\mathrm{AB} O \mathrm{Ox} 7$ against Thy-1.1 (Sera-Lab); goat antiserum against human fibronectin (LETS protein; Cappel, NC).

The specific antibodies were visualized by the corresponding antimouse, anti-rabbit, or anti-goat-FITC or -RITC linked secondary antibodies (Cappel, NC). Prior to staining, the cultures were washed twice with PBS containing $5 \%$ sucrose and $0.1 \%$ BSA. The antibodies $\mathrm{O}_{1}, \mathrm{O}_{4}$, and $\mathrm{A}_{2} \mathrm{~B}_{5}$ were directed against surface antigens and were therefore incubated on the living cultures at room temperature for $30 \mathrm{~min}$ at a dilution of 1:20 in PBS/sucrose/BSA. Antibodies against Thy-1 were diluted 1:10, anti-fibronectin 1:20. The cultures were then rinsed twice, fixed for $10 \mathrm{~min}$ with $4 \%$ formalin in PBS, rinsed again, incubated for $1 \mathrm{hr}$ with the labeled secondary antibodies (dilution 1:30-1:100), washed, and mounted in PBS:glycerol (1:1). For double-labeling experiments of $\mathrm{A}_{2} \mathrm{~B}_{5}$ or $\mathrm{O}_{1}$ antibodies with the $\mathrm{O}_{4}$ antibody, living cultures were first incubated with antibodies $\mathrm{A}_{2} \mathrm{~B}_{5}$ or $\mathrm{O}_{1}$, followed by anti-mouse-FITC and then with antibody $\mathrm{O}_{4}$; after fixation, this was followed by antimouse-RITC. In order to detect $\mathrm{A}_{2} \mathrm{~B}_{5}$ or $\mathrm{O}_{1}$ labeled cells which do not carry the $\mathrm{O}_{4}$ antigen, the sequence was reversed in some experiments. Staining for GFAP was done on cultures previously fixed in $95 \%$ ethanol $/ 5 \%$ acetic acid for $30 \mathrm{~min}$ at $4^{\circ} \mathrm{C}$ and rehydrated into PBS. In the case of $\mathrm{O}_{4} / \mathrm{GFAP}$ double-labeling experiments, staining with the $\mathrm{O}_{4}$ antibody was done first on the living cultures, followed by $10 \mathrm{~min}$ fixation in $4 \%$ formalin and then by ethanol/acetic acid treatment and GFAP staining. For visualization of MBP, the cultures were briefly fixed in $4 \%$ formalin, then treated with ethanol/acetic acid, and finally incubated with anti-MBP antiserum (1:500) for $1 \mathrm{hr}$ at room temperature. Ethanol/acetic acid fixation was also used for visualization of neurofilaments.

Evaluation of double-labeled cultures. Cultures were systematically screened in the fluorescence microscope for the presence of one antigen (usually $\mathrm{O}_{4}$ ), and every labeled cell was examined for the presence of the other antigen, e.g., $A_{2} B_{5}, O_{1}$, or GFAP.

Evaluation of cocultures with nerve cells, neuroblastoma cells, or $3 T 3$ cells. Antibody-labeled cultures were systematically screened in the fluorescence microscope, and all $\mathrm{O}_{4}$-labeled cells were photographed. The same fields were photographed under phase-contrast illumination. The oligodendrocyte surface area occupied by or in contact with neurons, neurites, ganglionic Schwann cells, or 3T3 cells was estimated, and the oligodendrocytes were grouped into 3 categories: cells with $<20,20$ 80 , or $>80 \%$ of the territory covered by neurons, neurites, or $3 \mathrm{~T} 3$ cells. (Single thin processes, especially of immature cells, were often excluded from evaluation for reasons of comparability with the dense process network of highly branched oligodendrocytes.) In experiments with retinal cells, total oligodendrocyte territory and areas overlapped by retinal cells were measured with a Hewlett-Packard digitizer. The oligodendrocyte subtypes were identified on the corresponding fluorescence micrographs. The criteria used were cell morphology and antigenic characteristics $\left(\mathrm{O}_{4} / \mathrm{O}_{1}\right)$. $\mathrm{A}_{2} \mathrm{~B}_{5}$ staining could not be used as a marker for immature cells, since this antigen was rapidly lost (without a concomitant change in cell morphology-unpublished observations) after coculture with neurons. The distinguishing morphological criteria were shape and size of the cell body, number of primary processes, branching pattern of processes, and the occurrence of anastomoses and membrane sheets within the process network. With these criteria, highly branched oligodendrocyles and immature oligodendrocytes could be reproducibly distinguished. Most (but not all) of the highly branched cells were positive for the $\mathrm{O}_{1}$ antigen; immature cells were consistently negative.

Quantification of the direction of neuroblastoma process outgrowth with respect to highly branched oligodendrocytes was done as illustrated in Figure 6. Highly branched oligodendrocytes were sampled systematically, and neighboring neuroblastoma cells were classified as "adjacent" if the distance between the edge of the oligodendrocyte process network and the NB-2A cell was less than 2 cell body diameters. Further cells were classified as "distant" (see Fig. 5). A circle with 8 sectors (4 classes) was overlaid over the center of each neuroblastoma cell and oriented towards the nearest oligodendrocyte cell body; the neuroblastoma processes were then counted in each sector (see Fig. 6 and Table 2).

Preparation of rnyelin. Spinal cords were dissected from $200 \mathrm{gm}$ rats, carefully cleaned from adhering dorsal and ventral roots, and homogenized (Polytron, $30 \mathrm{sec}$ at half-maximal speed). Sciatic nerves were dissected, minced, and homogenized. Myelin fractions were isolated by flotation of low-speed supernatants on sucrose density gradients (Colman et al., 1982). In some experiments, to remove possible trapped contaminants, the crude membrane fraction was washed following hypotonic shock. Sedimentation in hypotonic medium was achieved at $10,000 \times g$ for $5 \mathrm{~min}$. Membrane fractions in sucrose solutions containing no more than $50 \mathrm{~mm}$ ionic species were adsorbed for several hours onto the wells of polylysine-coated tissue culture dishes (about $0.1 \mathrm{mg}$ of protein $/ \mathrm{cm}^{2}$ of tissue culture dish). Unbound membranes were removed by 3 washes with CMF-Hank's solution. Coated dishes 

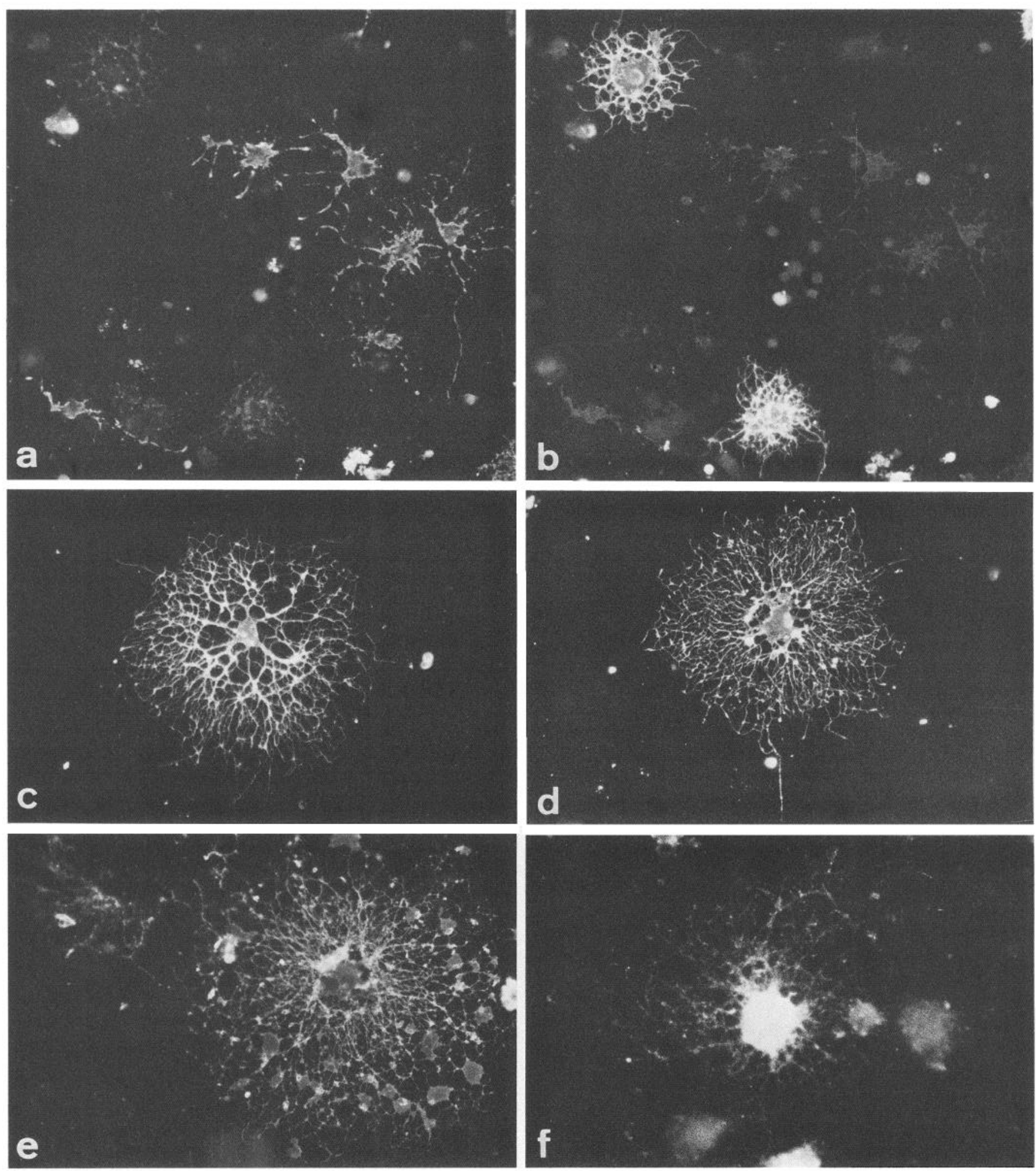

Figure 1. Typical morphologies and antigenic characteristics of immature oligodendrocytes $(a)$ and highly branched oligodendrocytes $(b-f)$. The antigenic profile $\left(\mathrm{A}_{2} \mathrm{~B}_{5}^{-}, \mathrm{O}_{4}^{+}, \mathrm{O}_{1}^{+}\right.$, often $\left.\mathrm{MBP}^{+}\right)$suggests that highly branched oligodendrocytes are actively involved in myelin synthesis. $a$ and $b$, Double-stained culture of 7-d-old optic nerve glial cells $\left(2 \mathrm{~d}\right.$ in vitro): $\mathrm{A}_{2} \mathrm{~B}_{5}(a)$ labels immature oligodendrocytes and type II astrocytes; $\mathrm{O}_{1}(b)$ exclusively labels highly branched oligodendrocytes. $\times 200 . c$ and $d$, Highly branched oligodendrocytes from adult rat optic nerves $(8 \mathrm{~d}$ in vitro) stained with antibody $\mathrm{O}_{4}(c)$ or $\mathrm{O}_{1}(d)$. $\times 300$. e. Highly branched oligodendrocyte from 10-d-old rat optic nerve $\left(14 \mathrm{~d}\right.$ in vitro) stained with $\mathrm{O}_{4}$. Process network contains flat membrane areas. $\times 300 . f$, MBP-positive oligodendrocyte (8-d-old optic nerve, $2 \mathrm{~d}$ in vitro). $\times 700$. 
Table 1. Oligodendrocyte subpopulations characterized by antibody labeling

\begin{tabular}{|c|c|c|c|c|c|c|}
\hline \multirow[b]{2}{*}{ Population } & \multicolumn{6}{|c|}{ Percentage of labeled cells } \\
\hline & $\mathrm{A}_{2} \mathrm{~B}_{5}{ }^{+} \mathrm{O}_{4}^{-}$ & $\mathrm{A}_{2} \mathrm{~B}_{5}+/ \mathrm{O}_{4}{ }^{+}$ & $\mathrm{A}_{2} \mathrm{~B}_{5}{ }^{-} / \mathrm{O}_{4}{ }^{+}$ & $\mathrm{A}_{2} \mathrm{~B}_{5}^{+} / \mathrm{O}_{1}^{-}$ & $\mathrm{A}_{2} \mathrm{~B}_{5}{ }^{+} / \mathrm{O}_{1}{ }^{+}$ & $\mathrm{A}_{2} \mathrm{~B}_{5}{ }^{-} / \mathrm{O}_{1}{ }^{+}$ \\
\hline Highly branched oligodendrocytes & 0 & $9 \pm 4$ & $91 \pm 4$ & 0 & $7+2$ & $93 \pm 2$ \\
\hline \multicolumn{7}{|c|}{ Cells with irregular or polygonal shapes } \\
\hline Flat, membranous cells & $37 \pm 4^{a}$ & $51 \pm 6$ & $12 \pm 6$ & 100 & 0 & 0 \\
\hline Process-bearing cells & $18 \pm 5$ & $74 \pm 5$ & $8 \pm 2$ & $84 \pm 6$ & $14 \pm 6$ & $1.5 \pm 1.5$ \\
\hline Cells with filopodia & 0 & $57 \pm 8$ & $43 \pm 8$ & 91 & 1 & $(8 \pm 8)^{b}$ \\
\hline
\end{tabular}

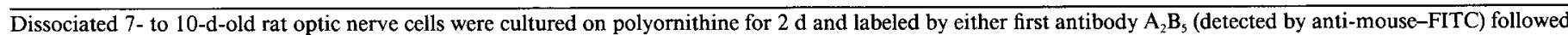

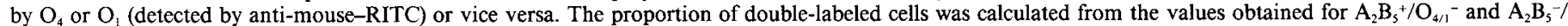
$\mathrm{O}_{4 / 1}{ }^{+}$cells. Values represent the means \pm SEM of 4-6 cultures (120-200 cells/culture) from 2 separate experiments.

${ }^{a}$ This population of $\mathrm{A}_{2} \mathrm{~B}_{5}{ }^{+} / \mathrm{O}_{4}{ }^{-}$cells contains type II astrocytes and precursor cells not expressing any oligodendrocyte marker.

${ }^{b}$ Variable, weak, granular staining.

were then immediately used in substrate testing experiments. In experiments with sympathetic or sensory neurons, small droplets of central or peripheral myelin were deposited in defined patterns over $35 \mathrm{~mm}$ culture dishes.

Sympathetic or sensory neurons cultured as described before were examined after $12 \mathrm{hr}-4 \mathrm{~d}$, neuroblastoma cells after 5-24 hr, and 3T3 cells after $1-4$ hr. For quantification, neuroblastoma cells were classified as round cells, cells with filopodia or short processes, or cells with processes longer than one cell body diameter. 3T3 cells were classified as round cells, cells with filopodia or short processes, or large flat cells. Three to four micrographs per culture were taken at random from 3 cultures for each experimental point.

\section{Results}

Cultures of dissociated young or adult rat optic nerves

GFAP-positive astrocytes accounted for about $30 \%$ of the cells in dissociatcd 10-d-old rat optic nerves. About 50\% of the cells were positive for the $\mathrm{O}_{4}$ antigen, a marker for differentiated, (GalC-positive) and immature $\left(\mathrm{A}_{2} \mathrm{~B}_{5}\right.$-positive) oligodendrocytes. No overlap was seen in the labeling between $\mathrm{O}_{4}$ and GFAP or $\mathrm{O}_{4}$ and Thy-1, confirming the specificity of the $\mathrm{O}_{4}$ antibody as a marker for the oligodendrocyte family (Sommer and Schachner, 1981). Thy-1-positive fibroblasts with large flat morphologies accounted for about $20 \%$ of the cells in young rat optic nerves.

\section{Subtypes of oligodendrocytes}

In culcures from 7 - to 10 -d-old rats, about $50 \%$ of the $\mathrm{O}_{4}$-positive cells were $\mathrm{A}_{2} \mathrm{~B}_{5}$-positive. $\mathrm{A}_{2} \mathrm{~B}_{5}$-labeled cells were $\mathrm{O}_{1}$-negative (Table 1; Fig. 1, $a, b$ ) and had different morphologies, including cells with irregular processes from polygonal cell bodies, flat cells with peripheral processes, bipolar cells, or cells decorated with filopodia. On the basis of this marker profile $\left(\mathrm{A}_{2} \mathrm{~B}_{5}{ }^{+}, \mathrm{O}_{4}{ }^{+}\right.$, $\mathrm{O}_{1}^{-}$), and in agreement with Schnitzer and Schachner (1982), we interpret these cells as being precursor and immature oligodendrocytes. They are collectively called "immature oligodendrocytes" in the following. This cell group is probably heterogenous, as suggested also by the different morphologies. Filopodia-carrying cells may be the most advanced (Table 1).

About $50 \%$ of the $\mathrm{O}_{4}$-positive cells were $\mathrm{A}_{2} \mathrm{~B}_{5}$-negative and $\mathrm{O}_{1}$-positive after $2 \mathrm{~d}$ in culture under our culture conditions. Most of these cells showed a typical, highly branched radial process network. Because of this characteristic morphology we called these cells highly branched oligodendrocytes (Fig. 1, b-f; Table 1). After $2 \mathrm{~d}$ in culture, most highly branched oligodendrocytes from optic nerves of 10 -d-old rats were stained with an antiserum against myelin basic protein (MBP) (Fig. 1f). We therefore interpret these cells as being myelin-forming oligo- dendrocytes. Their characteristic process network may be the result of an unstable, partially collapsed myelin membrane containing occasional flat membrane areas (Figs. $1 e, 5 d$ ).

The total yield of cells from adult nerves was very low. Both differentiated $\mathrm{O}_{1}$-positive highly branched oligodendrocytes (Fig. 1d) and immature $\mathrm{A}_{2} \mathrm{~B}_{5}$-positive oligodendrocytes were also present in cultures of adult tissue.

\section{Coculture with sympathetic or sensory neurons}

Dissociated cells from newborn rat superior cervical ganglia or dorsal root ganglia were added to glial cells after $2-10 \mathrm{~d}$ in culture. In part of the experiments, ganglionic Schwann cells and fibroblasts were eliminated by pulses of Ara C. NGF (50 or $100 \mathrm{ng} / \mathrm{ml}$ ) was added to the culture medium, leading to a rapid fiber outgrowth and to the formation of dense neurite networks within a few days. NGF alone had no effect on the occurrence and morphology of oligodendrocytes. Glial cell types were identified by antibody staining at the end of the experiments $(2 \mathrm{~d}-$ 2 weeks of coculture).

In cultures with a dense neurite plexus, the most striking observation was the occurrence of "windows" free of neurites, in the center of which cells with radial, highly branched processes could be observed (Fig. 2). Antibody staining identified these cells as highly branched oligodendrocytes. A quantification of the interaction of oligodendrocytes with sympathetic ganglion cells is shown in Figure $3, A, B$. Astrocytes adjacent to oligodendrocytes were rare in these cultures since the overall glial cell density was low; preferential association with astrocytes, therefore, could not account for this result. Highly branched oligodendrocytes excluded neurons from their territory, irrespective of the culture substrate used. The same "windows" were formed on plain plastic, collagen, polyornithine-, or laminin-coated culture dishes. No difference was seen between sympathetic and sensory neurons; both were excluded from the territory of highly branched oligodendrocytes. Likewise, Schwann cells, when present, did not invade or overgrow the oligodendrocyte process networks (Fig. $2 b$ ). In contrast, immature oligodendrocytes, characterized by their irregular shapes and the absence of $\mathrm{O}_{1}$ antigen, did allow neurite growth on their processes and cell bodies (Figs. $2 e, f ; 3 B$ ). $\mathrm{A}_{2} \mathrm{~B}_{5}$ could not be used as a marker for immature oligodendrocytes in cocultures with neurons, as this antigen was rapidly lost after addition of the neurons (M. Schwab, unpublished observations). Recent direct observations of the encounter of growth cones with oligodendrocytes showed us that growth cone movement is arrested after filopodial contact is established. Normal growth cone activity 

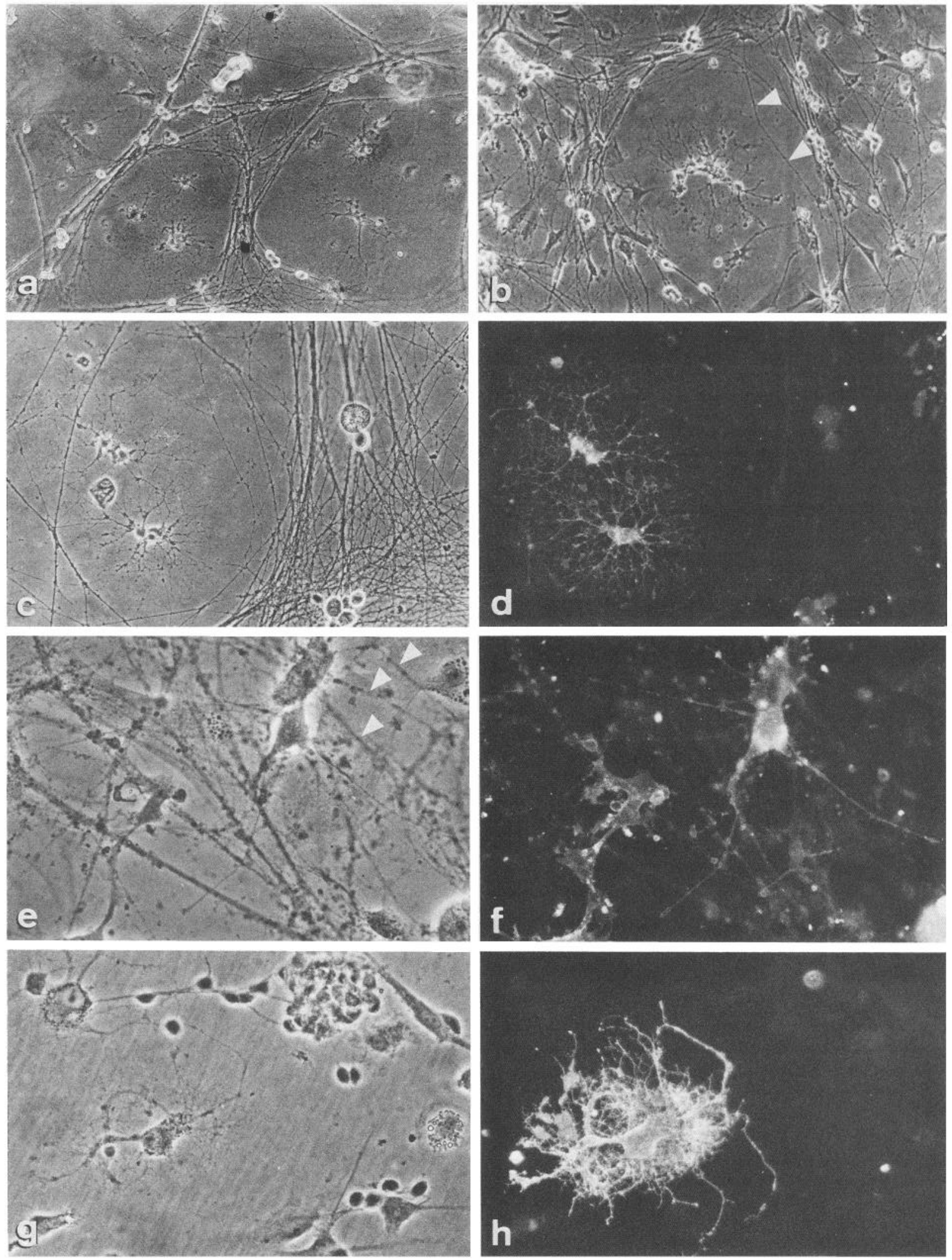

Figure 2. Sympathetic $(a-f)$ or retinal $(g, h)$ neurons plated into cultures of optic nerve glial cells show nonpermissive substrate effect of highly branched oligodendrocytes and its absence in immature oligodendrocytes. $a$ and $b$, "Windows" formed by highly branched oligodendrocytes (10$\mathrm{d}$-old optic nerves, $18 \mathrm{~d}$ in vitro) in the neurite plexus of sympathetic neurons $(a, 8 \mathrm{~d}$ in vitro; $b, 4 \mathrm{~d}$ in vitro). $\times 120$. In $b$, a neurite changing its direction is seen (arrowhead). Schwann cells also avoid the oligodendrocyte. $c$ and $d, \mathrm{O}_{4}$-positive oligodendrocytes (from 10-d-old optic nerves, 23 $\mathrm{d}$ in vitro) surrounded by plexus of sympathetic neurites $(13 \mathrm{~d}$ in vitro $) \times 220$. Neurites characteristically "loop around" the oligodendrocytes. The occasional spanning of neurite bundles over nonpermissive oligodendrocytes occurs as a secondary event. $a$ and $c$, no astrocytes are present in the field. $e$ and $f, \mathrm{O}_{4}$-positive cells with typical morphology of immature oligodendrocytes are permissive for sympathetic neurites (arrowheads) ( $5 \mathrm{~d}$ in vitro). $\times 380 . \mathrm{g}$ and $h$, E20 rat retinal cells $(2 \mathrm{~d}$ in vitro $)$ do not adhere or grow neurites onto highly branched, $\mathrm{O}_{1}$-positive $(h)$ oligodendrocyte. $\times 200$. 


\section{Highly branched oligodendrocytes}

Figure 3. $A$ and $B$, Histograms showing the frequency of interactions/overlap of sympathetic neurites and Schwann cells with highly branched $(A)$ or immature $(B)$ oligodendrocytes. Glial cells from 8- to 10-d-old optic nerves ( $2 \mathrm{~d}$ in vitro) were cocultured for additional $2 \mathrm{~d}$ with dissociated neurons from superior cervical ganglia and then stained with $\mathrm{O}_{4}$. Oligodendrocytes were classified by morphology on coded fluorescence pictures. On phase-contrast pictures, the fractional area of contact with neurites and Schwann cells was determined and classified into 3 categories: $<20,20-80$, or $>80 \%$ of oligodendrocyte territory covered by neurites or Schwann cells. Values represent mean frequencies of cells in the 3 categories \pm SEM ( 4 cultures; 70-130 systematically sampled cells per culture). $C$ and $D$, Histograms showing the interaction on retinal cells with highly branched $(C)$ or immature $(D)$ oligodendrocytes. Glial cultures from adult rat optic nerves (6-11 d in vitro) were cocultured for $1-5 \mathrm{~d}$ with embryonic rat retinal cells. $\mathrm{O}_{4}$-stained oligodendrocytes were classified morphologically, and the total area occupied by each oligodendrocyte, as well as the fraction occupied by retinal cells, was determined by measuring with a graphic tablet. $n=$ 109.
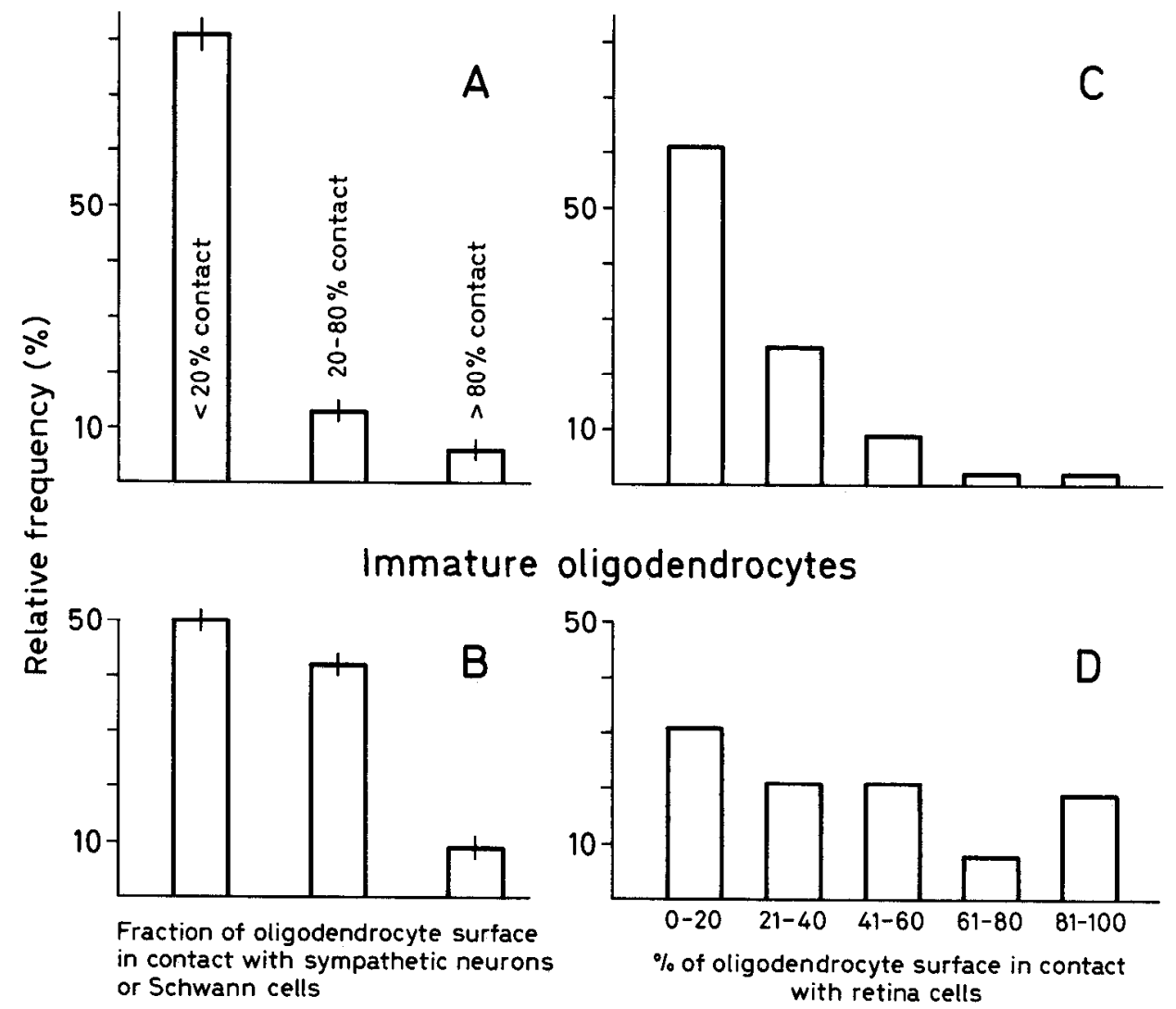

was seen during contact and crossing of immature cells ( $T$. Zachleder and M. Schwab, unpublished observations). These observations also exclude that the "windows" were formed secondarily in the neurite plexus.

Astrocytes in the same cultures were often overgrown by single neurites or neurite bundles (Fig. 4, $a, b$ ). This was true for both morphological types, flat and stellate cells.

\section{Cocultures with fetal rat retinal cells}

After plating retinal cells at monolayer density on top of 5-dold cultures of optic nerve non-neuronal cells, a typical rearrangement of the retinal cells was observed: whereas oligodendrocyte precursor cells were often contacted by retinal cells, the highly branched oligodendrocytes were mostly free of them (Figs. $2, g, h ; 3, C, D)$. Again, astrocytes were preferred as a substrate over polyornithine (Fig. $4, c, d$ ).

\section{Response of other cell types to highly branched oligodendrocytes}

Neuroblastoma cells (line NB-2A) were plated at high cell density into dissociated optic nerve cultures and stimulated for fiber production by $2 \mathrm{~mm}$ dibutyryl-cyclic AMP or by GdNPF. At 7,24 , or $48 \mathrm{hr}$, the cultures were fixed and oligodendrocytes were identified by antibodies $\mathrm{O}_{4}$ and $\mathrm{O}_{1}$. Again, the territories of highly branched oligodendrocytes were clearly spared by neuroblastoma cells (Fig. 5, $a, b$ ). Processes produced by neuroblastoma cells situated close to oligodendrocytes were pointing away from the oligodendrocytes (Figs. 5, $a, b ; 6$ and Table 2).

Primary culture fibroblasts and astrocytes in the optic nerve preparations and mouse $3 T 3$ cells showed a drastic "avoidance behavior" towards highly branched oligodendrocytes. 3T3 cells plated at high cell density into optic nerve glial cultures attached and flattened out between $30 \mathrm{~min}$ and $3 \mathrm{hr}$ on the polyornithine substrate. In these forming monolayers, characteristic "windows" appeared corresponding to the territories of highly branched oligodendrocytes (Fig. $5 c-f$ ). At the sites of contact $3 \mathrm{~T} 3$ cells formed a crescent-shaped bulge of cytoplasm. Lamellipodia were absent in this region. Significantly, fibroblasts that landed directly on highly branched oligodendrocytes completely failed to spread. As for neurons, immature oligodendrocytes were not visibly avoided by $3 \mathrm{~T} 3$ cells (Figs. $5, e, f ; 7$ ).

\section{Absence of species specificity}

In addition to $\mathrm{O}_{4}$-positive/ $\mathrm{A}_{2} \mathrm{~B}_{5}$-positive precursor cells, dissociated non-neuronal cells from E13 and E1 7 chick optic nerve also contained the characteristic $\mathrm{O}_{4}$-positive $/ \mathrm{A}_{2} \mathrm{~B}_{5}$-negative $/ \mathrm{O}_{1}$ positive highly branched oligodendrocytes. $3 \mathrm{~T} 3$ cells plated on top of chicken non-neuronal cells formed characteristic "windows" around these chick oligodendrocytes. These findings show that neither the specific morphology nor the unfavorable substrate property of oligodendrocytes is species specific (data not shown).

\section{Myelin as a substrate}

Since myelin consists of spirally wrapped oligodendrocyte membranes, we were interested in testing the properties of myelin as a substrate for neurons or fibroblasts. Crude myelin fractions from adult rat spinal cord or sciatic nerve were prepared by flotation on a sucrose gradient. The myelin was adsorbed to polylysine-coated tissue culture dishes and tested for its sub- 

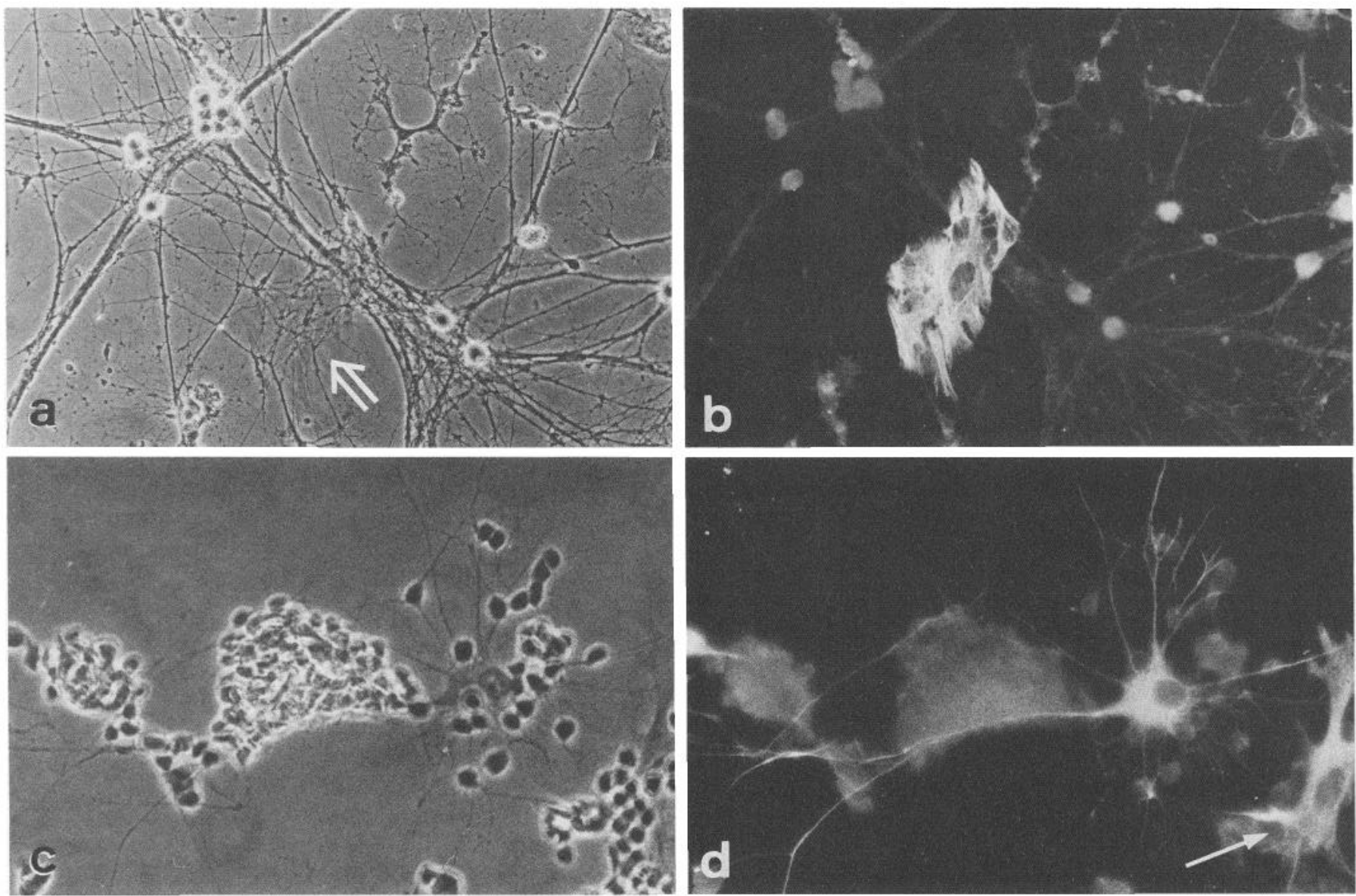

Figure 4. Astrocytes represent an adhesive substrate for neurons and neurites. $a$ and $b$, Sympathetic neurites (13 $\mathrm{d}$ in vitro) growing on reactive, GFAP-positive $(b)$ protoplasmic astrocyte (arrow in $a$ ) (from 10-d-old rat optic nerve, $23 \mathrm{~d}$ in vitro). $\times 220 . c$ and $d$, Retinal cells (from E17 retina, $2 \mathrm{~d}$ in vitro) adhering to astrocytes (GFAP-positive; from 10-d-old optic nerve, $9 \mathrm{~d}$ in vitro) with long and with short (arrow) processes. $\times 400$.

strate properties for superior cervical ganglion cells, dorsal root ganglion cells, neuroblastoma cells, and 3T3 cells. All 4 cell types were attaching poorly to CNS myelin and showed marked difficulty in their process outgrowth. Sympathetic and sensory neurons on CNS myelin remained round or produced short, abortive fibers despite the presence of NGF $(50$ or $100 \mathrm{ng} / \mathrm{ml}$; Fig. 8, $a, c)$. In contrast, long fibers were produced on islets of sciatic nerve myelin in the same culture dishes (Fig. 8, $b, d$ ). Small CNS myelin islets on polylysine appeared as "windows" outlined by excluded neurites, whereas PNS myelin-polylysine boundaries were apparently not detected by growing neurites (Fig. 8, $c, d$ ).

Process outgrowth from neuroblastoma cells (line NB-2A) in the presence of dibutyryl-cyclic AMP was significantly reduced by CNS myelin (Fig. 9A).

Spreading of $3 T 3$ fibroblasts was strongly inhibited by CNS myelin (Figs. 9B, 10). 3T3 cells remained round or produced spindle-shaped or polygonal morphologies with a minimal cell substrate interaction. In contrast, large flat membranes were produced within 20-30 min on polylysine and, with a somewhat slower time course, also on myelin from the PNS (Figs. 9B, 10). Nonpermissiveness was associated, at least in large part, with myelin membranes since sedimentation at $10,000 \mathrm{~g}$ for $5 \mathrm{~min}$ under hypotonic conditions (see Materials and Methods) was sufficient to pellet most nonpermissive membranes. Under these conditions, most surface membrane components floating to den- sities smaller than the one of 0.85 m sucrose would not be expected to sediment.

These experiments show that, in parallel to the effects of living, highly branched oligodendrocytes, myelin from the CNS is also a strongly nonpermissive substrate for primary culture neurons, neuroblastoma cells, and 3T3 fibroblasts. Myelin from the PNS does not show a comparable nonpermissive substrate effect. Our experiments do not exclude the possibility that PNS myelin permissiveness is due to contaminating basement membrane components, which would adhere tightly to the myelin membranes. CNS myelin nonpermissiveness, however, is not due to astrocyte membranes, since a cell membrane preparation from CNS tissue containing minimal amounts of white matter (superficial cortical layers) was a permissive substrate for fibroblast spreading (P. Caroni and M. E. Schwab, unpublished observations).

\section{Discussion}

Cell attachment, spreading, and motility, and, in particular, neurite outgrowth, are strongly dependent on cell-substrate interactions (Sanes, 1983; Carbonetto, 1984). An increasing number of substrate molecules favoring neuroblast migration or neurite outgrowth are currently being found and characterized in central and peripheral nervous tissue (Cornbrooks et al., 1983; Edelman, 1984; Liesi, 1985b; Stallcup et al., 1985; Chiu et al., 

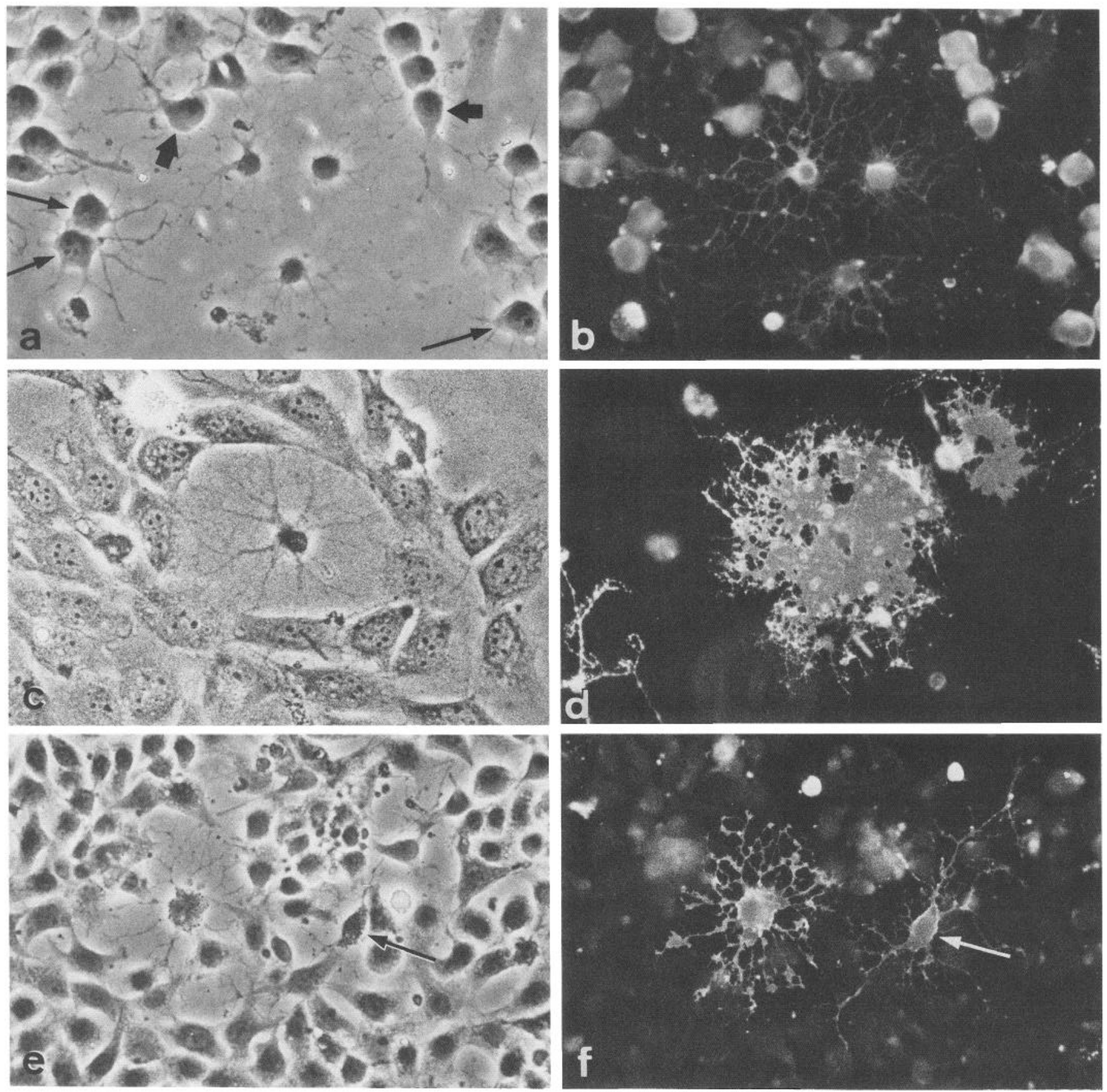

Figure 5. $a$ and $b$, Highly branched oligodendrocytes $\left(\mathrm{O}_{4}\right.$-positive $)$ are nonpermissive for attachment and fiber outgrowth of NB-2A neuroblastoma cells. NB-2A cells were cultured for $24 \mathrm{hr}$ on optic nerve glial cells (6-d-old rat optic nerves, $3 \mathrm{~d}$ in culture) and stimulated for neurite outgrowth by GdNPF (Guenther et al., 1986). NB-2A cells adjacent to oligodendrocytes (short arrows) show asymmetric outgrowth, distant cells (long arrows) show random orientation of outgrowth (see Fig. 6). $\times 260 . c-f, 3 T 3$ fibroblasts plated at high cell densities into optic nerve glial cultures show nonpermissive substrate effect of highly branched oligodendrocytes $(c$ and $e$ ). The oligodendrocyte in $c$ and $d$ has large membrane areas connecting its process network. An immature oligodendrocyte ( $e$ and $f:$ arrow; $\mathrm{O}_{4}$-positive, irregular morphology) is overgrown by spreading fibroblasts. Ten$(c, d)$ and 12- $(e, f)$ d-old optic nerves, $2 \mathrm{~d}$ in vitro; $3 \mathrm{~T} 3$ added for $3 \mathrm{hr}$. $d$ and $f, \mathrm{O}_{4}$ staining; $c$ and $d ; \times 300 ; e$ and $f, \times 250$.

1986; Fischer et al., 1986; Lindner et al., 1986; Mirsky et al., 1986; Carbonetto et al., 1987). The appearance of some of these constituents can be correlated with specific developmental stages and, in the PNS, also with denervation (Edelman, 1984; Liesi, 1985b; Stallcup et al., 1985; Daniloff et al., 1986; Carbonetto et al., 1987). The absence of one such component, laminin, in the differentiated mammalian CNS, in contrast to the PNS or lower vertebrate $\mathrm{CNS}$, suggested the hypothesis that the absence of this favorable substrate could be crucial for the absence of neurite regeneration in the CNS of higher vertebrates (Hopkins et al., 1985; Liesi, 1985a; Carbonetto et al., 1987). In the present study, we observed that myelin-forming oligodendrocytes and isolated CNS myelin exert a nonpermissive substrate effect on outgrowing neurites of sympathetic and sensory neurons and neuroblastoma cells, as well as for the attachment of retinal cells and the spreading of fibroblasts. In cerebellar cultures, a similar 


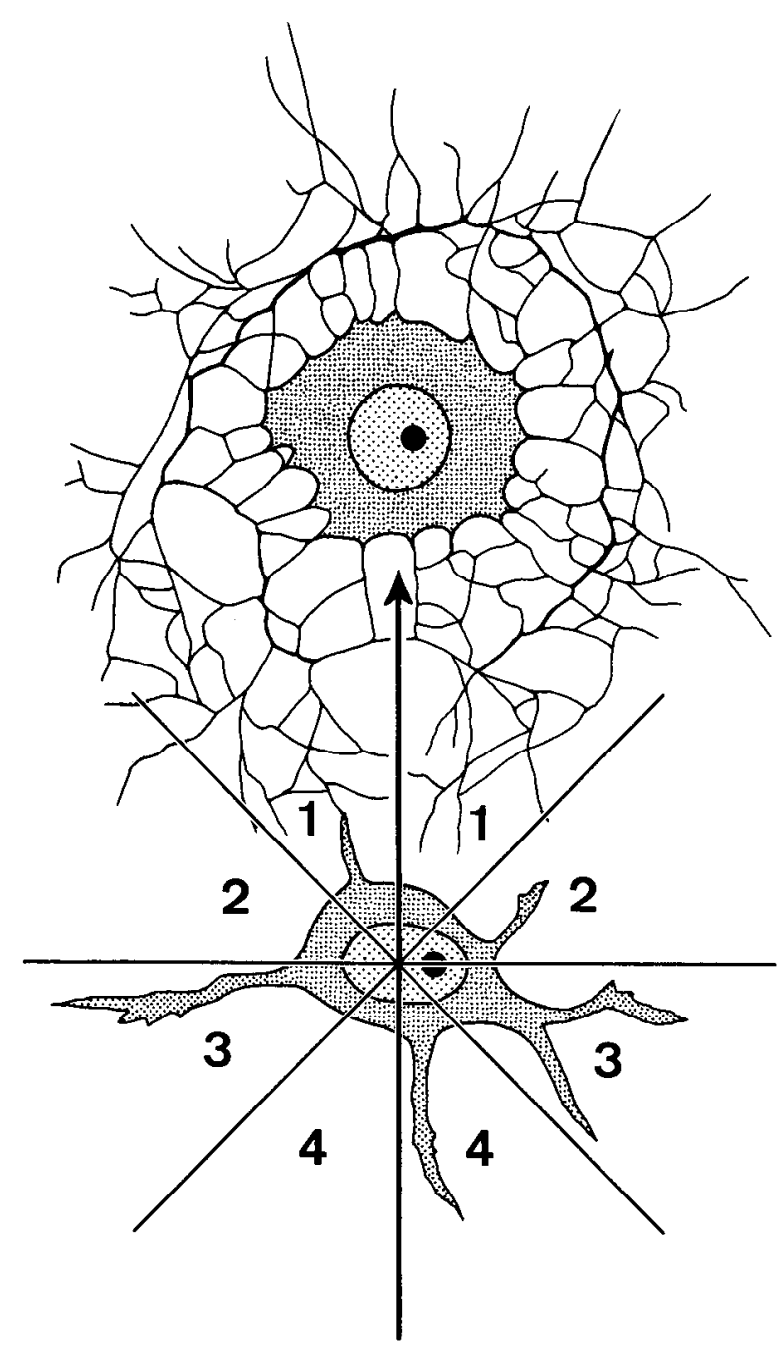

Figure 6. Orientation of neuroblastoma process outgrowth in relation to highly branched oligodendrocytes. Optic nerve glial cells $(2$ or $6 \mathrm{~d}$ in vitro) were cocultured with NB-2A cells for $24 \mathrm{hr}$ in the presence of GdNPF or dibutyryl cAMP. $\mathrm{O}_{4}$-positive, highly branched oligodendrocytes were systematically sampled and neighboring neuroblastoma cells were classified as adjacent when the distance between the edge of oligodendrocyte process network and neuroblastoma cell body was less than 2 cell body diameters (Fig. $5, a, b$ ). Neuroblastoma cells at greater distances were classified as distant. Neuroblastoma processes were assigned to 4 sectors $(1-4)$ according to their direction with regard to the closest oligodendrocyte as illustrated. Values in Table 2 represent means \pm SEM of 3 experiments (60-100 neurites from 3 cultures per experiment). ${ }^{*} p<0.05 ;{ }^{* * *} p<0.001$.

Table 2. Orientation of neuroblastoma processes with regard to highly branched oligodendrocytes

Percentage of processes in each sector

\begin{tabular}{lll}
\hline Sector & $\begin{array}{l}\text { Adjacent neuro- } \\
\text { blastoma cells }\end{array}$ & $\begin{array}{l}\text { Distant neuro- } \\
\text { blastoma cells }\end{array}$ \\
\hline 1 & $7 \pm 1.4$ & $25 \pm 2.4^{\mathrm{a}}$ \\
2 & $34 \pm 1.2$ & $26 \pm 1.2^{\mathrm{a}}$ \\
3 & $33 \pm 2.7$ & $25 \pm 2.3^{b}$ \\
4 & $26 \pm 2.3$ & $24 \pm 2.7$ \\
\hline
\end{tabular}

\footnotetext{
${ }^{\circ p} p<0.001$.
}

${ }^{n} p<0.05$.

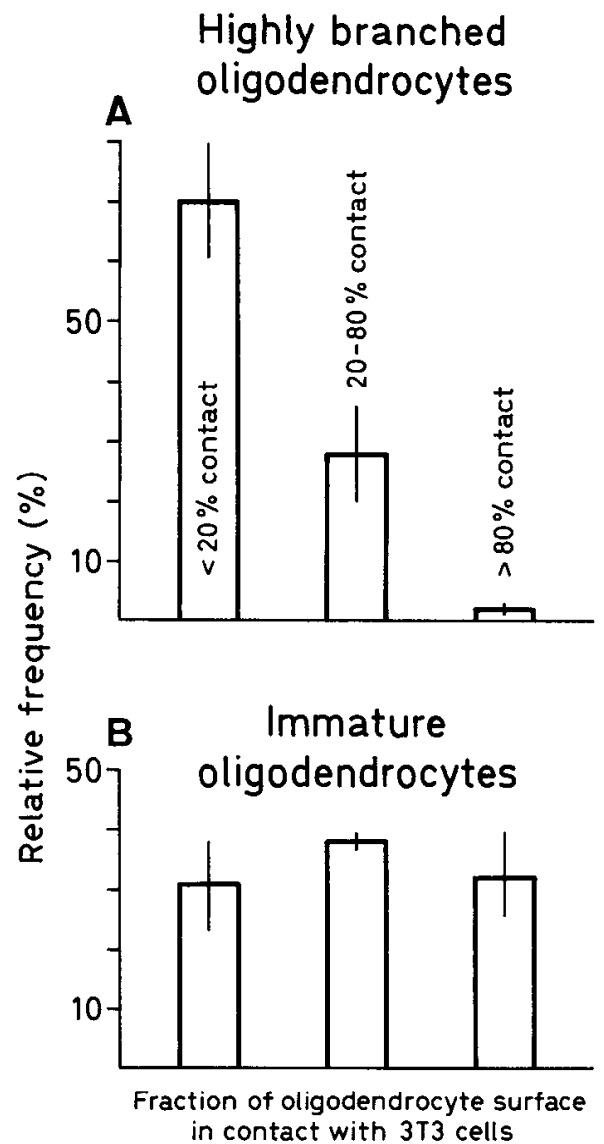

Figure 7. Histograms showing the overlap of 3T3 cells with highly branched $(A)$ or immature $(B)$ oligodendrocytes. 3 T3 cells were cocultured for 3-4 hr on optic nerve glial cells at high cell density, and cultures were fixed and stained with $\mathrm{O}_{4}$. Oligodendrocytes were sampled systematically, classified as highly branched or immature oligodendrocytes and their overlap with $3 T 3$ cells determined in the 3 categories indicated. Values represent means \pm SEM of 4 experiments $(70-170$ cells).

lack of association of neurons with GalC-positive oligodendrocytes, in contrast to astrocytes, was described by Hatten et al. (1984)

Several classes of cells were present in short-term cultures of dissociated rat optic nerves: oligodendrocytes, astrocytes (GFAPpositive), fibroblasts (Thy-1-, fibronectin-positive), and several types of precursor cells. Within the oligodendrocyte family $\left(\mathrm{O}_{4}\right.$ positive; Sommer and Schachner, 1981), one main cell subtype was characterized by the absence of the $\mathrm{O}_{1}$ antigen $(\mathrm{GalC})$ and of MBP, 2 components highly characteristic of myelin (Mirsky et al., 1980), and the presence of binding sites for the antibody $A_{2} B_{5} . A_{2} B_{5}$ was shown to be a marker for oligodendrocyte/type II astrocyte precursors, type II astrocytes, and neurons (Abney et al., 1981; Schnitzer and Schachner, 1982; Raff et al., 1983). Therefore, we considered this cell class to represent immature oligodendrocytes, probably including precursors as those described by Dubois-Dalcq (1986) and Sommer and Noble (1986). The presence of $\mathrm{O}_{4}$ distinguishes these cells from the $\mathrm{O} 2 \mathrm{~A}$ precursors (Raffet al., 1983). These immature cells showed irregular and variable morphologies with bipolar shapes or polygonal cell bodies and irregular processes, often decorated with filopodia. The cell class is probably heterogenous; cell division could be observed (F. Dutly and M. E. Schwab, unpublished observations). The second main oligodendrocyte subclass consisted 

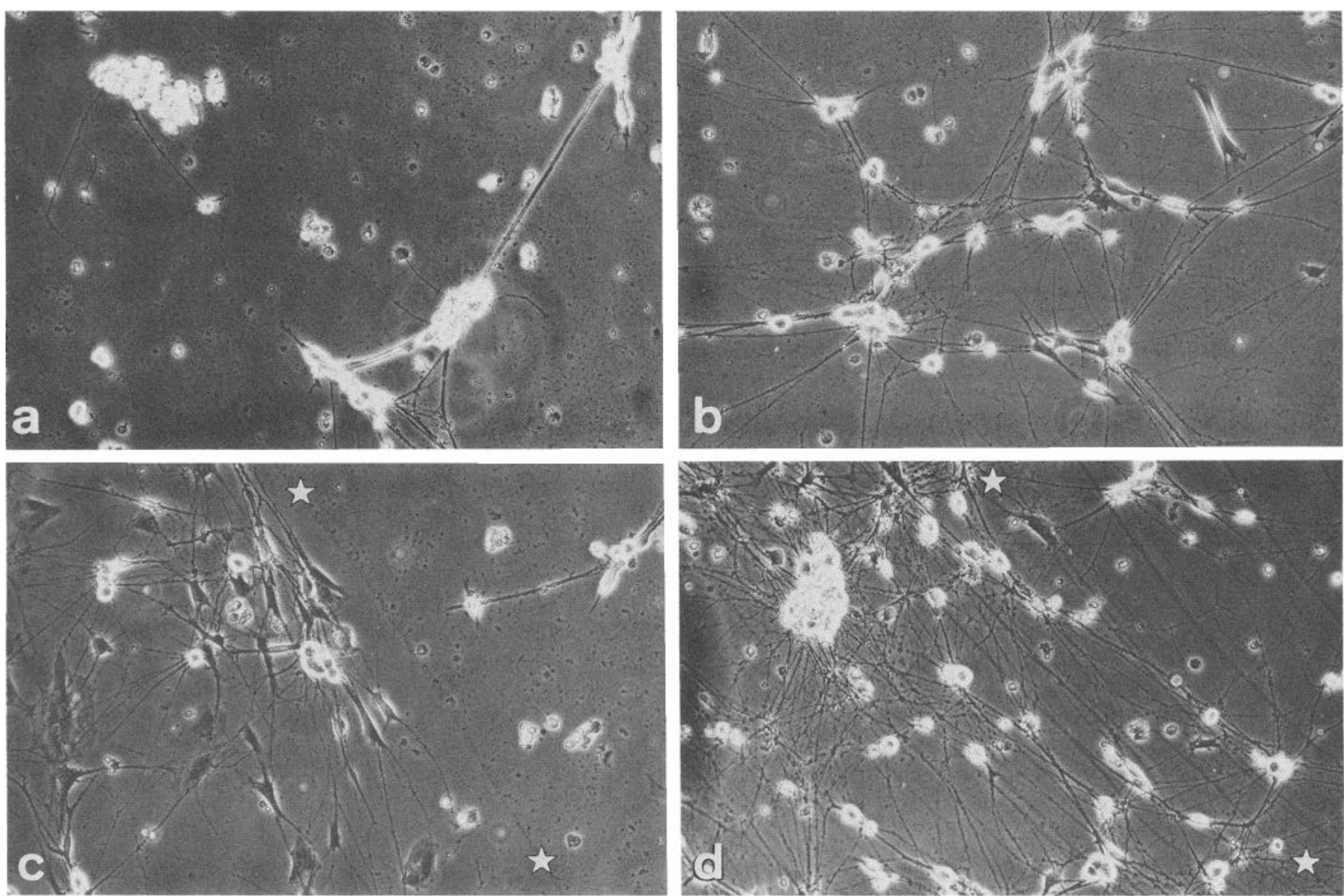

Figure 8. Inhibition of neurite outgrowth by CNS myelin as a substrate. Sympathetic neurons (from 1-d-old rat superior cervical ganglia) cultured in presence of $100 \mathrm{ng} / \mathrm{ml} \mathrm{NGF}$ for $26 \mathrm{hr}$ on polylysine-coated culture dish containing focal spots of CNS or PNS myelin. CNS myelin $(a, c)$ strongly inhibits neurite outgrowth; PNS myelin $(b, d)$ is a permissive substrate. In $c$ and $d$, the border of a myelin islet on the polylysine is shown (asterisk). $\times 75$.

of $\mathrm{A}_{2} \mathrm{~B}_{5}$-negative, GalC-positive cells possessing a radial, highly branched, and anastomosing process network. Most of these highly branched oligodendrocytes in 2-d-old cultures of 10-dold rat optic nerves were positive for MBP under our culture conditions. We thus interpret this frequent cell type as representing oligodendrocytes actively involved in the synthesis of myelin membranes. In the absence of axons, these membranes are deposited flat on the culture substrate; as such they are unstable and collapse to form the characteristic, anastomosing process network. This cell type has been described as "hairy eyeball cell" (Sommer and Schachner, 1981), and formation of whorls of compact myelin by such cells has been observed after prolonged times in culture (Rome et al., 1986; Yim et al., 1986).

Both immature and myelin-forming oligodendrocytes were seen in cultures of 7- to 10-d-old or adult rat optic nerves and also in cultures of 1-d-old rat optic nerves, newborn rat spinal cord, and adult rat corpus callosum (unpublished observations), as well as in cultures of spinal cord and optic nerves of E13 or E17 chick embryos. Immature cells were clearly predominant in dissociates from younger stages, but the large drop in cell yield upon dissociation with increasing age precluded any quantitative population analysis. However, immature oligodendrocytes could also be obtained consistently from adult rat white matter tissues, confirming earlier observations by ffrench-Constant and Raff (1986).
The addition of neurons to established glial cultures showed dramatic differences in substrate properties for neuronal attachment and fiber outgrowth among the various types of nonneuronal cells. Astrocytes, in particular the flat reactive protoplasmic astrocytes were adhesive and favorable for neuronal attachment and outgrowth, in agreement with earlier observations (Foucaud et al., 1982; Hatten et al., 1984; Noble et al., 1984; Fallon, 1985). Immature oligodendrocytes were also frequently contacted by neurites or nerve cell bodies. This behavior could have significant physiological relevance. During development, oligodendrocyte precursors migrate into the already formed axonal bundles and extend processes to contact a certain number of axons. These processes then start to enwrap and spiral around the axons, thus forming the structure called myelin (Wood and Bunge, 1984).

In sharp contrast to astrocytes and oligodendrocyte precursors, we found that myelin-forming oligodendrocytes display strongly nonpermissive substrate properties for neuronal attachment and fiber outgrowth, as well as for fibroblast attachment and spreading. This effect was strong and pronounced even on laminin-coated culture dishes, which otherwise represent an excellent substrate for neurite growth (Manthorpe et al., 1983; Rogers et al., 1983). This effect could not be overcome by high doses of NGF in cultures of sympathetic and sensory neurons or GdNPF or dibutyryl-cyclic AMP in cultures of neuroblas- 
A Neuroblastoma cells, $5 \mathrm{hr}$
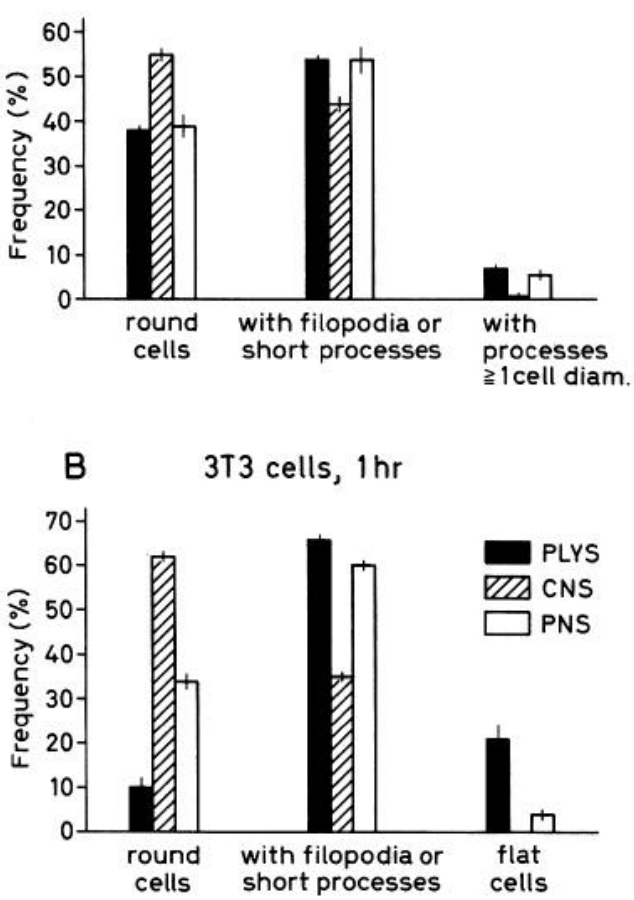

Figure 9. Nonpermissive substrate effects of CNS myelin but not PNS myelin for neurite outgrowth from neuroblastoma cells $(A)$ and for 3T3 cell spreading $(B)$. $A$, Neuroblastoma cells cultured for $5 \mathrm{hr}$ in presence of 2 mM dibutyryl cAMP on polylysine (solid bars), CNS myelin-coated polylysine (hatched bars), or PNS myelin-coated polylysine (open bars). Cells were classified as round cells, filopodia or short process carrying cells or cells with processes longer than 1 cell diameter. Values represent means \pm SEM of 3 cultures ( $250-450$ cells per culture). $B, 3 T 3$ cells cultured for $1 \mathrm{hr}$ on polylysine, CNS myelin-coated polylysine, or PNS myelin-coated polylysine. Cells were classified as round cells, cells with filopodia or short processes, or large flat cells. Values represent means \pm SEM of 3 cultures (300-400 cells per culture).

toma cells. A similar or identical nonpermissive substrate property was associated with rat CNS myelin but not with myelin from peripheral nerves. The effect was strictly contact-dependent, since nerve cells or fibroblasts grew well and were free to move in the immediate surrounding of these oligodendrocytes or of CNS myelin islets. Mouse 3T3 cells were also inhibited by chicken oligodendrocytes, showing that this effect is not species specific. Recent biochemical studies have shown that the activity is due to specific myelin and oligodendrocyte membrane proteins (Caroni and Schwab, 1988a, b). As expected from the difference from peripheral myelin, the general physicochemical properties of myelin and the myelin lipids are unrelated to this effect. The fact that mobility of neuronal growth cones, as well as of fibroblast lamellipodia, is inhibited suggests a common underlying cell biological mechanism, which is currently under investigation.

In the rat optic nerve, the peak number of axons is reached at embryonic day 20, followed by a dramatic loss of axons (Crespo et al., 1985). Oligodendrocyte precursors appear from E17 on (Raff et al., 1985) and express GalC around birth (Miller et al., 1985). The first myelin detectable by electron microscopy appears at postnatal day 6 (Hildebrand and Waxman, 1984). This clear-cut temporal dissociation between axonal growth and myelin formation is also present in chicken optic nerves (Rager, 1980) and, although less well studied, in many white matter
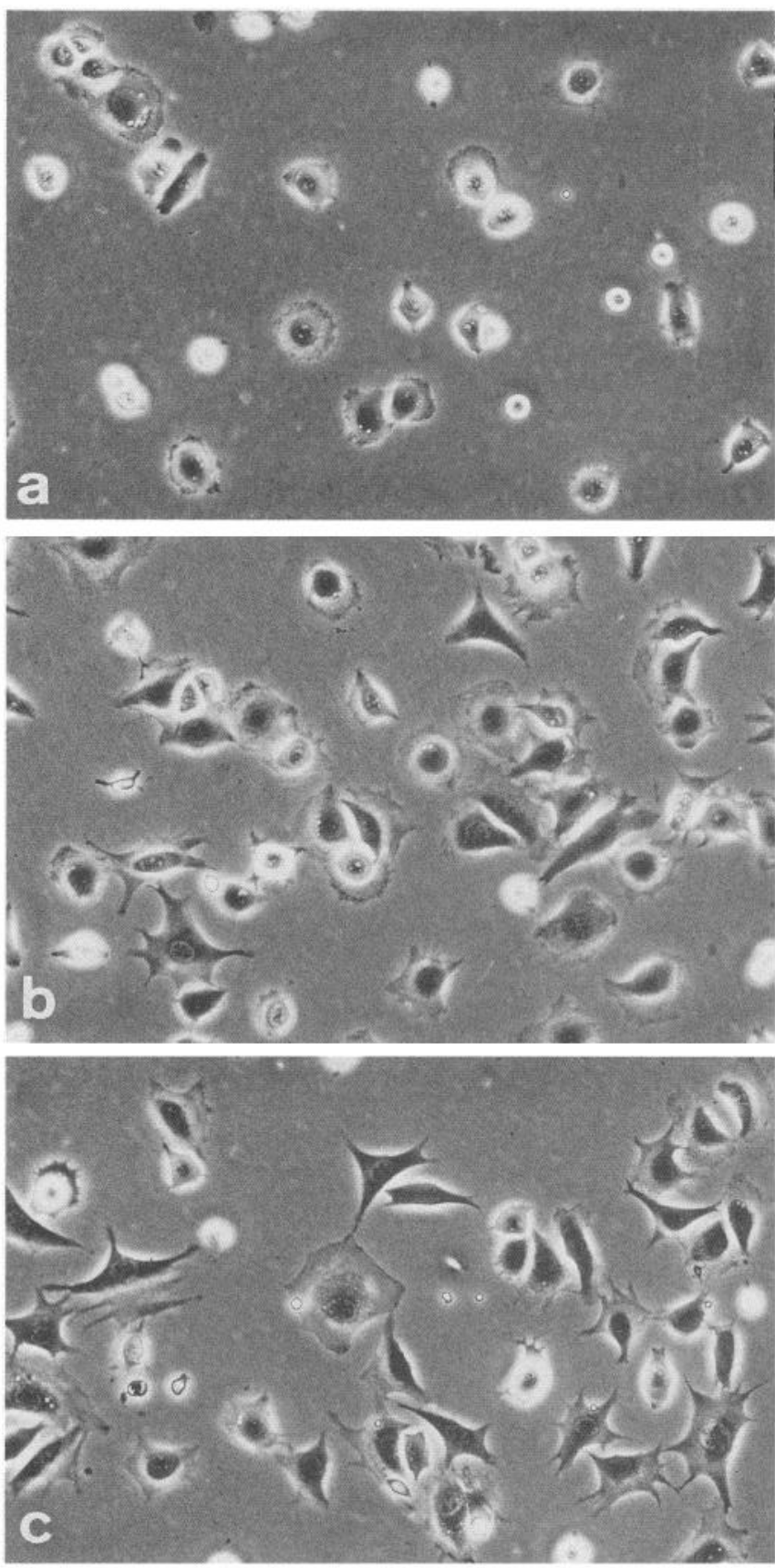

Figure 10. Spreading of $3 \mathrm{~T} 3$ cells $(1 \mathrm{hr})$ on polylysine coated with CNS myelin $(a)$, PNS myelin $(b)$, or on polylysine alone $(c)$. Round cells or cells with short processes are predominant on the CNS myelin. $\times 170$.

tracts of the CNS (Matthews and Duncan, 1971; Looney and Elberger, 1986). During normal development, growing axons therefore probably never encounter myelin or myelinating oligodendrocytes within their fascicles but, rather, interact with precursors and immature oligodendrocytes. The extremely slow time course observed for in vitro myelination (Wood et al., 1980; Wood and Williams, 1984) could be consistent with a situation in which undifferentiated oligodendrocytes first interact with axons and are then induced to differentiate and form myelin.

The physiological significance of the potent nonpermissive substrate property of oligodendrocytes and myelin remains to be investigated. In contrast to development, axonal growth cones 
or sprouts do encounter mature oligodendrocytes and myelin during CNS regeneration. Substrate properties of CNS tissue, in particular the absence of potent neurite promoting substrates like laminin in the differentiated CNS of higher vertebrates, are important aspects in the context of CNS regeneration (Liesi, 1985a; Carbonetto et al., 1987). However, since myelin and oligodendrocytes persist for a long time in denervated CNS tracts (Fulcrand and Privat, 1977; Bignami et al., 1981), the absence of any fiber regeneration in white matter areas, in contrast to peripheral nerves and PNS/CNS transplants, could be related to these nonpermissive substrate factors. Implantations of fetal, well-regenerating adrenergic or cholinergic neurons into spinal cords or hippocampus have shown that some long-distance fiber growth can be observed in adult brain tissue, which is, however, strictly confined to gray matter areas (Kromer et al., 1981; Nornes et al., 1983; Björklund and Stenevi, 1984; Commissiong, 1984).

Under normal conditions, blocking certain territories for later-growing axonal populations during development, antagonism between favorable and nonpermissive substrate molecules during development of CNS projection patterns, or spatial limitation of sprouting in the differentiated CNS are possible functions for this oligodendrocyte-associated nonpermissive substrate property.

\section{References}

Abney, E. R., P. P. Bartlett, and M. C. Raff (1981) Astrocytes, ependymal cells, and oligodendrocytes develop on schedule in dissociated cell cultures of embryonic rat brain. Dev. Biol. 83: 301-310.

Abney, E. R., B. P. Williams, and M. C. Raff (1983) Tracing the development of oligodendrocytes from precursor cells using monoclonal antibodies, fluorescence-activated cell sorting, and cell culture. Dev. Biol. 100: 166-171.

Abrahamson, I. K., P. A. Wilson, and R. A. Rush (1986) Production and transport of endogenous trophic activity in a peripheral nerve following target removal. Dev. Brain Res. 27: 117-126.

Barde, Y.-A., D. Edgar, and H. Thoenen (1982) Purification of a new neurotrophic factor from mammalian brain. EMBO J. 1: 549-553.

Benfey, M., and $\Lambda$. J. Aguayo (1982) Extensive elongation of axons from rat brain into peripheral nerve grafts. Nature 296: 150-152.

Bignami, A., D. Dahl, B. T. Nguyen, and C. J. Crosby (1981) The fate of axonal debris in Wallerian degeneration of rat optic and sciatic nerves. J. Neuropathol. Exp. Neurol. 40: 537-550.

Björklund, A., and U. Stenevi (1984) Intracerebral neural implants: Neuronal replacement and reconstruction of damaged circuitries. Annu. Rev. Neurosci. 7: 279-308.

Carbonetto, S. (1984) The extracellular matrix of the nervous system. Trends Neurosci. 7: 382-387.

Carbonetto, S., D. Evans, and P. Cochard (1987) Nerve fiber growth in culture on tissue substrates from central and peripheral nervous systems. J. Neurosci. 7: 610-620.

Caroni, P., and M. E. Schwab (1988a) Two membrane protein fractions from rat central myelin with inhibitory propertics for neurite growth and fibroblast spreading. J. Cell Biol. (in press).

Caroni, P., and M. E. Schwab (1988b) Antibody against myelin-associated inhibitor of neurite growth neutralizes non-permissive substrate properties of CNS white matter. Neuron 1: 85-96.

Chiu, A. Y., W. D. Matthew, and P. H. Patterson (1986) A monoclonal antibody that blocks the activity of a neurite regeneration-promoting factor: Studies on the binding site and its localization in vivo. J. Cell Biol. 103: 1383-1398.

Colman, D. R., G. Kreibich, A. B. Frei, and D. D. Sabatini (1982) Synthesis and incorporation of myelin polypeptides into CNS myelin. J. Cell Biol. 95: 598-608.

Commissiong, J. W. (1984) Fetal locus coeruleus transplanted into the transected spinal cord of the adult rat: Some observations and implications. Ncuroscience 12: 839-853.

Cornbrooks, C. J., D. J. Carey, J. A. McDonald, R. Timpl, and R. P.
Bunge (1983) In vivo and in vitro observations on laminin production by Schwann cells. Proc. Natl. Acad. Sci. USA 80: 3850-3854.

Crespo, D., D. D. M. O'Leary, and W. M. Cowan (1985) Changes in the numbers of optic nerve fibers during late prenatal and postnatal development in the albino rat. Dev. Brain Res. 19: 129-134.

Dahl, D., and A. Bignami (1976) Immunogenic properties of the glial fibrillary acidic protein. Brain Res. 116: 150-157.

Daniloff, J. K., G. Levi, M. Grumet, F. Rieger, and G. M. Edelman (1986) Altered expression of neuronal cell adhesion molecules induced by nerve injury and repair. J. Cell Biol. 103: 929-945.

Dubois-Dalcq, M. (1986) Interclonal variation in oligodendrocyte differentiation. Soc. Neurosci. Abstr. 12: 767.

Edelman, G. M. (1984) Expression of cell adhesion molecules during embryogenesis and regeneration. Exp. Cell Res. 161: 1-16.

Fallon, J. R. (1985) Preferential outgrowth of central nervous system neurites on astrocytes and Schwann cells as compared with nonglial cells in vitro. J. Cell Biol. 100: 198-207.

ffrench-Constant, C., and M. C. Raff (1986) Proliferating bipotential glial progenitor cells in adult rat optic nerve. Nature 319: 499-502.

Fischer, F., V. Künemund, and M. Schachner (1986) Neurite outgrowth patterns in cerebellar microexplant cultures are affected by antibodies to the cell surface glycoprotein L1. J. Neurosci. 6: 605612.

Foucaud, B., R. Reeb, M. Sensenbrenner, and G. Gombos (1982) Kinetic and morphological analysis of the preferential adhesion of chick embryo neuronal cells to astroglial cells in culture. Exp. Cell Res. 137: 285-294.

Fulcrand, J., and A. Privat (1977) Neuroglial reactions secondary to Wallerian degeneration in the optic nerve of the postnatal rat: Ultrastructural and quantitative study. J. Comp. Neurol. 176: 189-224.

Guenther, J., H. Nick, and D. Monard (1986) A glia-derived neuritepromoting factor with protease inhibitory activity. EMBO J. 4: 19631966.

Hatten, M. E., R. K. M. Liem, and C. A. Mason (1984) Two forms of cerebellar glial cells interact differently with neurons in vitro. J. Cell Biol. 98: 193-204.

Hildebrand, C., and S. G. Waxman (1984) Postnatal differentiation of rat optic nerve fibers: Electron microscopic observations on the development of nodes of Ranvier and axoglial relations. J. Comp. Neurol. 224: 25-37.

Hopkins, J. M., T. S. Ford-Holevinski, J. P. McCoy, and B. W. Agranoff (1985) Laminin and optic nerve regeneration in the goldfish. J. Neurosci. 5: 3030-3038.

Johnson, J. E., Y.-A. Barde, M. E. Schwab, and H. Thoenen (1986) Brain-derived neurotrophic factor supports the survival of cultured rat retinal ganglion cells. J. Neurosci. 6: 3031-3038.

Korsching, S., G. Auburger, R. Heumann, J. Scott, and H. Thoenen (1985) Levels of nerve growth factor and its mRNA in the central nervous system of the rat correlate with cholinergic innervation. EMBO J. 4: 1389-1393.

Kromer, L. F., A. Björklund, and U. Stenevi (1981) Regeneration of the septohippocampal pathways in adult rats is promoted by utilizing embryonic hippocampal implants as bridges. Brain Res. 210: 173200.

Liesi, P. (1985a) Laminin-immunoreactive glia distinguish regenerative adult CNS systems from non-regenerative ones. EMBO J. 4: 2505-2511.

Liesi, P. (1985b) Do neurons in the vertebrate CNS migrate on laminin? EMBO J. 4: 1163-1170.

Lindner, J., G. Zinser, W. Werz, C. Goridis, B. Bizzini, and M. Schachner (1986) Experimental modification of postnatal cerebellar granule cell migration in vitro. Brain Res. 377: 298-304.

Longo, F. M., E. G. Hayman, G. E. Davis, E. Ruoslahti, E. Engvall, M. Manthorpe, and S. Varon (1984) Neurite-promoting factors and extracellular matrix components accumulating in vivo within nerve regeneration chambers. Brain Res. 309: 105-117.

Looney, G. A., and A. J. Elberger (1986) Myelination of the corpus callosum in the cat: Time course, topography, and functional implications. J. Comp. Neurol. 248: 336-347.

Mains, R. E., and P. H. Patterson (1973) Primary cultures of dissociated sympathetic neurons. J. Cell Biol. 59: 329-345.

Manthorpe, M., E. Engvall, E. Ruoslahti, F. M. Longo, G. E. Davis, and S. Varon (1983) Laminin promotes neuritic regeneration from cultured peripheral and central neurons. J. Cell Biol. 97: 1882-1890. Matthews, M. A., and D. Duncan (1971) A quantitative study of 
morphological changes accompanying the initiation and progress of myelin production in the dorsal funiculus of the rat spinal cord. $J$. Comp. Neurol. 142: 1-22.

Miller, R. H., S. David, R. Patel, E. R. Abney, and M. C. Kaff (1985) A quantitative immunohistochemical study of macroglial cell development in the rat optic nerve: In vivo evidence for two distinct astrocyte lineages. Dev. Biol. 111: 35-41.

Mirski, R., J. Winter, E. R. Abney, R. M. Pruss, J. Gavrilovic, and M. C. Raff (1980) Myelin-specific proteins and glycolipids in rat Schwann cells and oligodendrocytes in culture. J. Cell Biol. 84: 483-494.

Mirsky, R., K. R. Jessen, M. Schachner, and C. Goridis (1986) Distribution of the adhesion molecules N-CAM and L1 on peripheral neurons and glia in adult rats. J. Neurocytol. 15: 799-815.

Needels, D. L., M. Nieto-Sampedro, and C. W. Cotman (1986) Induction of a neurite-promoting factor in rat brain following injury or deafferentation. Neuroscience 18: 517-526.

Noble, M., J. Fok-Seang, and J. Cohen (1984) Glia are a unique substrate for the in vitro growth of central nervous system neurons. J. Neurosci. 4: 1982-1903.

Nornes, H., A. Björklund, and U. Stenevi (1983) Reinnervation of the denervated adult spinal cord of rats by intraspinal transplants of embryonic brain stem neurons. Cell Tissue Res. 230: 15-35.

Omlin, F. X., M. F. Webster, C. G. Palkovits, and S. R. Cohen (1982) Immunocytochemical localization of basic protein in major dense line regions of central and peripheral myelin. J. Cell Biol. 95: 242248.

Raff, M. C., K. L. Fields, S. I. Hakomori, R. Mirsky, R. M. Pruss, and J. Winter (1979) Cell-type-specific markers for distinguishing and studying neurons and the major classes of glial cells in culture. Brain Res. 174: 283-318.

Raff, M. C., R. H. Miller, and M. Noble (1983) A glial progenitor cell that develops in vitro into an astrocyte or an oligodendrocyte depending on culture medium. Nature 303: 390-396.

Raff, M. D., E. R. Abney, and J. Fok-Seang (1985) Reconstitution of a developmental clock in vitro: A critical role for astrocytes in the timing of oligodendrocyte differentiation. Cell 42: 61-69.

Rager, G. H. (1980) Development of the retinotectal projection in the chicken. Adv. Anat. Embryol. Cell Biol. 63: 1-92.

Ramon y Cajal, S. (1928) Degeneration and Regeneration of the Nervous System (Engl. transl. and reprint, 1959), Hafner, New York.

Richardson, P. M., and T. Ebendal (1982) Nerve growth activities in rat peripheral nerve. Brain Res. 246: 57-64.

Richardson, P. M., V. M. K. Issa, and A. Aguayo (1984) Regeneration of long spinal axons in the rat. J. Neurocytol. 13: 165-182.

Rogers, S. L., P. C. Letourneau, S. L. Palm, J. McCarthy, and L. T. Furcht (1983) Neurite extension by peripheral and central nervous system neurons in response to substratum-bound fibronectin and laminin. Dev. Biol. 98: 212-220.

Rome, L. H., P. N. Bullock, F. Chiapelli, M. Cardwell, A. M. Adinolfi, and D. Swanson (1986) Synthesis of a myelin-like membrane by oligodendrocytes in culture. J. Neurosci. Res. 15: 49-65.

Sanes, J. R. (1983) Roles of extracellular matrix in neural development. Annu. Rev. Physiol. 45: 581-600.

Schnitzer, J., and M. Schachner (1982) Cell type specificity of a neural cell surface antigen recognized by the monoclonal antibody A2B5. rell Tissue Res. 224: 625-636.

Schwab, M. E., and H. Thoenen (1985) Dissociated neurons regenerate into sciatic but not optic nerve explants in culture irrespective of neurotrophic factors. J. Neurosci. 5: 2415-2423.

Shelton, D. L., and L. F. Reichardt (1986) Studies on the expression of the $\beta$ nerve growth factor (NGF) gene in the central nervous system: Level and regional distribution of NGF mRNA suggest that NGF functions as a trophic factor for several distinct populations of neurons. Proc. Natl. Acad. Sci. USA 83: 2714-2718.

Singh, H., and S. E. Pfeiffer (1985) Myelin-associated galactolipids in primary cultures from dissociated fetal rat brain: Biosynthesis, accumulation, and cell surface expression. J. Neurochem. 45: 13711381.

So, K. F., and A. J. Aguayo (1985) Lengthy regrowth of cut axons from ganglion cells after peripheral nerve transplantation into the retina of adult rats. Brain Res. 328: 349-354.

Sommer, 1., and M. Noble (1986) Plasticity and commitment in oligodendrocyte development. Soc. Neurosci. Abstr. 12: 1585.

Sommer, I., and M. Schachner (1981) Monoclonal antibodies $\left(\mathrm{O}_{1}\right.$ to $\left.\mathrm{O}_{4}\right)$ to oligodendrocyte cell surface: An immunocytological study in the central nervous system. Dev. Biol. 83: 311-327.

Stallcup, W. B., L. L. Beasley, and J. M. I evine (1985) Antibody against nerve growth factor-inducible large external (NILE) glycoprotein labels nerve fiber tracts in the developing rat nervous system. J. Neurosci. 5: 1090-1101.

Tello, F. (1911) La influencia del neurotropismo en la regeneracion de los centros nerviosos. Trab. Lab. Invest. Biol. 9: 123-159.

Whittemore, S. R., M. Nieto-Sampedro, D. L. Needels, and C. W. Cotman (1985) Neuronotrophic factors for mammalian brain neurons: Injury induction in neonatal, adult and aged rat brain. Dev. Brain Res. 20: 169-178.

Whittemore, S. R., T. Ebendal, L. Lärkfors, L. Olson, A. Seiger, I. Strömberg, and H. Persson (1986) Developmental and regional expression of $\beta$ nerve growth factor messenger RNA and protein in the rat central nervous system. Proc. Natl. Acad. Sci. USA 83: $817-$ 821.

Whittemore, S. R., L. Lärkfors, T. Ebendal, V. R. Holets, A. Ericsson, and $H$. Persson (1987) Increased $\beta$-nerve growth factor messenger RNA and protein levels in neonatal rat hippocampus following specific cholinergic lesions. J. Neurosci. 7: 244-251.

Willard, M., and C. Simon (1981) Antibody decoration of neurofilaments. J. Cell Biol. 89: 198-205.

Wood, P., and R. P. Bunge (1984) The biology of the oligodendrocyte. In Oligodendroglia, W. T. Norton, ed., pp. 1-46, Plenum, New York.

Wood, P. M., and A. K. Williams (1984) Oligodendrocyte proliferation and CNS myelination in cultures containing dissociated embryonic neuroglia and dorsal root ganglion neurons. Dev. Brain Res. 12: 225241.

Wood, P., E. Okada, and R. P. Bunge (1980) The use of networks of dissociated rat dorsal root ganglion neurons to induce myelination by oligodendrocytes in culture. Brain Res. 196: 247-252.

Yim, S. H., S. Szuchet, and P. E. Polak (1986) Cultured oligodendrocytes. J. Biol. Chem. 261: 11808-11815. 